\title{
A FRAGMENTARY DINOSAUR FEMUR AND THE PRESENCE OF NEOTHEROPODA IN THE UPPER TRIASSIC OF BRAZIL
}

\author{
FELIPE L. PINHEIRO \\ Laboratório de Paleobiologia, Universidade Federal do Pampa, Campus São Gabriel, R. Aluízio Barros Macedo, \\ BR 290, km 423, CEP 97300-000, São Gabriel, RS, Brazil.felipepinheiro@unipampa.edu.br
}

\begin{abstract}
Although already widespread in Laurasia, the Gondwanan Norian record of Neotheropoda (Dinosauria) is scarce, with a single taxon reported for the Los Colorados Formation of Argentina. Here the distal end of a dinosaur left femur from the Riograndia Assemblage Zone of Brazil (Norian, Candelária Sequence, Paraná Basin) is described and compared. Although fragmentary, the specimen has a morphology compatible with its attribution to Neotheropoda, being this the first record of the clade from the Brazilian Triassic. The new specimen supports a cosmopolitan distribution of Neotheropoda during the Late Triassic and highlights the potential for the discovery of additional dinosaur clades in Norian rocks of southern Brazil.
\end{abstract}

Key words: Dinosauria, Gondwana, Norian, Theropoda.

RESUMO - Apesar de já bem distribuído no Laurásia, o registro gondwânico dos Neotheropoda (Dinosauria) é escasso no Noriano, com apenas um táxon reportado para a Formação Los Colorados da Argentina. Aqui é descrito um fragmento distal de um fêmur esquerdo de dinossauro, proveniente da Zona de Assembleia de Riograndia (Noriano, Sequência Candelária, Bacia do Paraná, Brasil). Embora fragmentário, o espécime apresenta morfologia compatível com sua atribuição a Neotheropoda, sendo este o primeiro registro deste táxon para o Triássico brasileiro. O novo espécime suporta uma distribuição cosmopolita dos Neotheropoda durante o Neotriássico, além de evidenciar o potencial de rochas do Noriano brasileiro para a descoberta de uma diversidade ainda oculta de dinossauros.

Palavras-chave: Dinosauria, Gondwana, Noriano, Theropoda.

\section{INTRODUCTION}

The Upper Triassic sedimentary record of Western Pangaea, especially as represented by the Chañares, Ischigualasto and Los Colorados formations of Argentina and the Candelária Sequence of Brazil (sensu Horn et al., 2014), provides rich and unique insights into the origins and early diversification of dinosaurs (e.g. Arcucci et al., 2004; Langer et al., 2010b; Marsicano et al., 2016). Compared with the well-sampled coeval deposits of Argentina, dinosaur diversity in Brazilian Late Triassic is still low, with only a few taxa known from the Hyperodapedon Assemblage Zone (AZ) and the younger Riograndia AZ (Norian) of the Candelária Sequence (Paraná Basin, e.g. Langer et al., 2010b) (Figure 1). Although neotheropod dinosaurs were relatively widespread during the Norian, this clade has not been previously reported from the Riograndia AZ of Brazil. As a matter of fact, even though neotheropod remains have been recovered from a number of mainly Laurasian norian fossil sites, representatives of this clade were rare during the Late Triassic. Only one neotheropod taxon is known for South American Upper Triassic, despite the fact that rocks of this series are well represented in that continent (Arcucci \& Coria, 2003; Ezcurra \& Novas, 2007).

Here, the distal end of a dinosaur left femur from a classic locality of the Riograndia AZ is described. The specimen is unlike the other taxa so far recorded for the Candelária Sequence and has a morphology compatible with Neotheropoda, indicating the presence of this clade in the Upper Triassic of Brazil.

Institutional abbreviations. MMACR, Museu Municipal Aristides Carlos Rodrigues, Candelária, RS, Brazil; NMMNH, New Mexico Museum of Natural History \& Science, Albuquerque, New Mexico, USA; SMNS, Staatliches Museum für Naturkunde, Stuttgart, Germany.

\section{SYSTEMATIC PALAEONTOLOGY}

Clade DINOSAURIA Owen, 1842

Suborder THEROPODA Marsh, 1881

Clade NEOTHEROPODA Bakker, 1986

(Figures 2A-J)

Material. MMACR $039 \mathrm{~T}$, distal portion of a left femur (Figures 2A-J). 
Locality, unit and age. The specimen comes from the 'Botucaraí Hill', a well-known Riograndia AZ site (Norian, Candelária Sequence, Paraná Basin) located in a road cut $6 \mathrm{~km}$ west of Candelária city, Rio Grande do Sul,

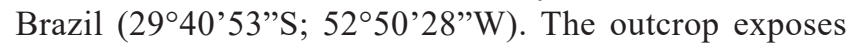
sandstones intercalated with mudstone lenses. Remains of sauropodomorphs from the 'Botucaraí Hill' site were reported by Bittencourt et al. (2013). The Norian age of 'Botucaraí Hill' site is based on the presence of the dicynodont genus Jachaleria, also known from the lower levels of the Los Colorados Formation (Soares et al., 2011).

Comparative description. MMACR 039 T (Figures 2A-J) is well preserved, lacking strong diagenetic alterations. The proximal end and most of the shaft are missing, and there is a superficial breakage that partially excavates the anterior surface of the bone. The preserved fragment is $37 \mathrm{~mm}$ long and $21 \mathrm{~mm}$ in lateromedial width, and measures $15 \mathrm{~mm}$ between its anterior margin and the posterior most extension of the medial (tibial) condyle.
The distal end is only slightly expanded lateromedially in relation to the shaft, a condition not observed in most Triassic dinosaurs, such as herrerasaurids (e.g. Novas, 1993), sauropodomorphs (e.g. Langer, 2003; Müller et al., 2015), Guaibasaurus (Bonaparte et al., 1999; Langer et al., 2010a) and ornithischians (e.g. Butler, 2010).

The distal anterior surface bears a faint extensor groove that is connected distally with a very discrete sulcus intercondylaris (Figures 2A,B). An extensor groove is regarded as a derived character, present in some abelisauroids and tetanurans (Ezcurra \& Novas, 2007), but absent in herrerasaurids, basal sauropodomorphs such as Saturnalia, basal ornithischians, such as Lesothosaurus and Eocursor, as well as some early theropods, such as Liliensternus, Coelophysis, Tawa and Zupaysaurus (e.g. Langer, 2003; Ezcurra \& Novas, 2007; Butler, 2010). The distal femur of herrerasaurids, Saturnalia, Eocursor and Tawa has a distinctly convex anterior surface. Guaibasaurus, Pampadromaeus, Eoraptor and Coelophysis (NMMNH 42351), although

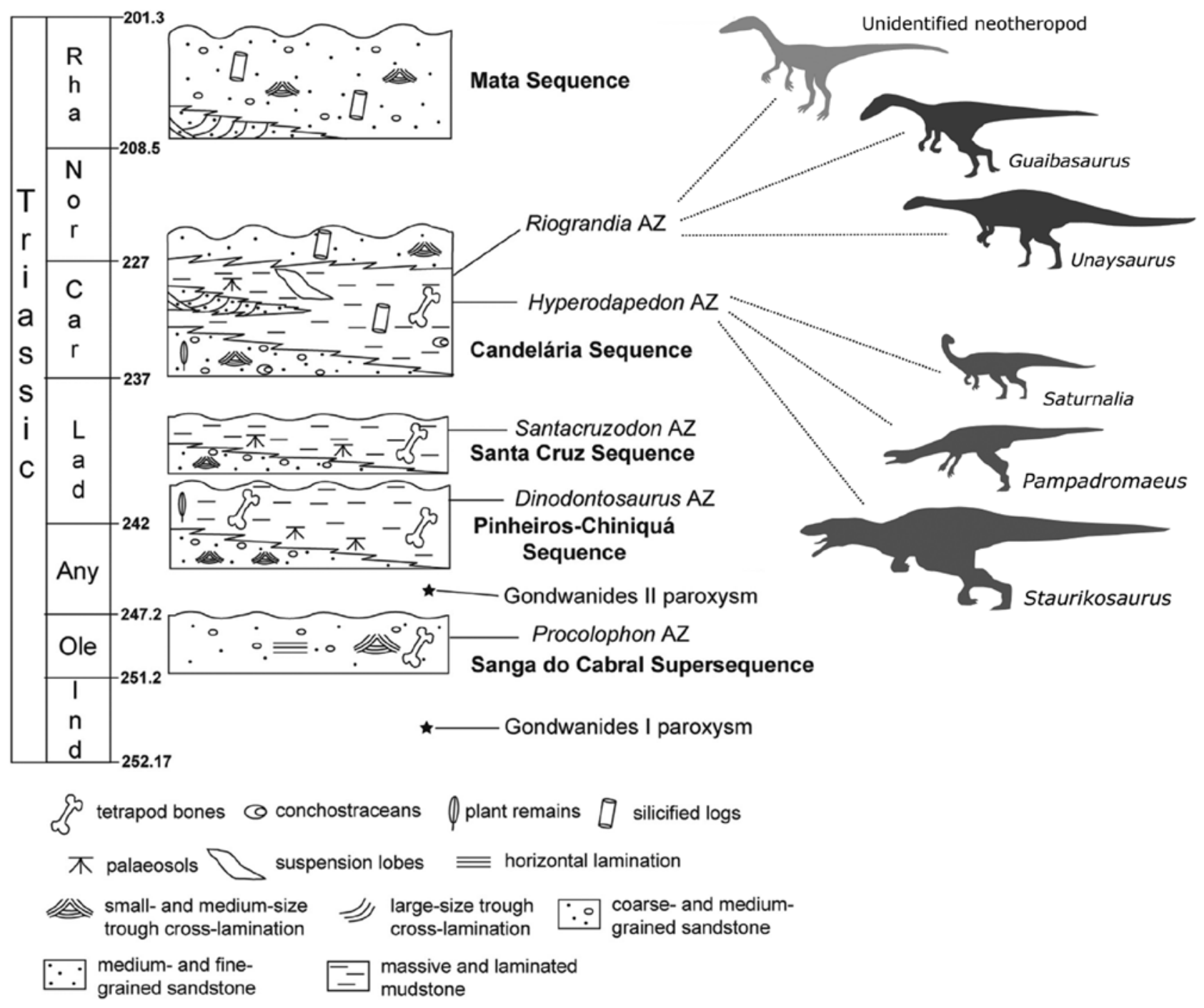

Figure 1. Southern Brazil Triassic chronostratigraphy, depicting vertebrate biozones and recovered dinosaur taxa. Modified from Zerfass et al. (2003) and Horn et al. (2014). Saturnalia, Pampadromaeus and Staurikosaurus silhouettes modified from Pretto et al. (2015). 
having a flat femoral anterior surface, lack an extensor groove (Bonaparte et al., 1999; Ezcurra \& Novas, 2007; Sereno et al., 2013; Müller et al., 2015).

A U-shaped popliteal fossa excavates the posterior surface of the specimen (Figures 2I,J). The depth of this fossa resembles the condition observed in Saturnalia, Pampadromaeus, Eoraptor and neotheropods, and is deeper than in herrerasaurids (Novas, 1993; Langer, 2003; Bittencourt \& Kellner, 2009; Alcober \& Martínez, 2010; Sereno et al., 2013; Müller et al., 2015).

The medial condyle is anteroposteriorly oriented, forming an angle of a little less than $90^{\circ}$ with the femoral anterior surface (Figures 2I,J). This contrasts with the obtuse-angled distal anteromedial corner developed in a number of basal dinosaurs. This character, however, is considerably variable among early dinosaurs, and may be influenced by size. An anteromedial corner forming an acute angle is more widespread among neotheropods, being present, for example, in Dilophosaurus, Streptospondylus (Welles, 1984; Allain, 2001) and Liliensternus (based on a replica of the syntype, deposited at the SMNS). On its posterior surface, the medial condyle of MMACR 039 ends in a small prominence, flanked ventromedially by a deep sulcus. This unusual structure is here interpreted as an epicondyle (Figures 2C,D).
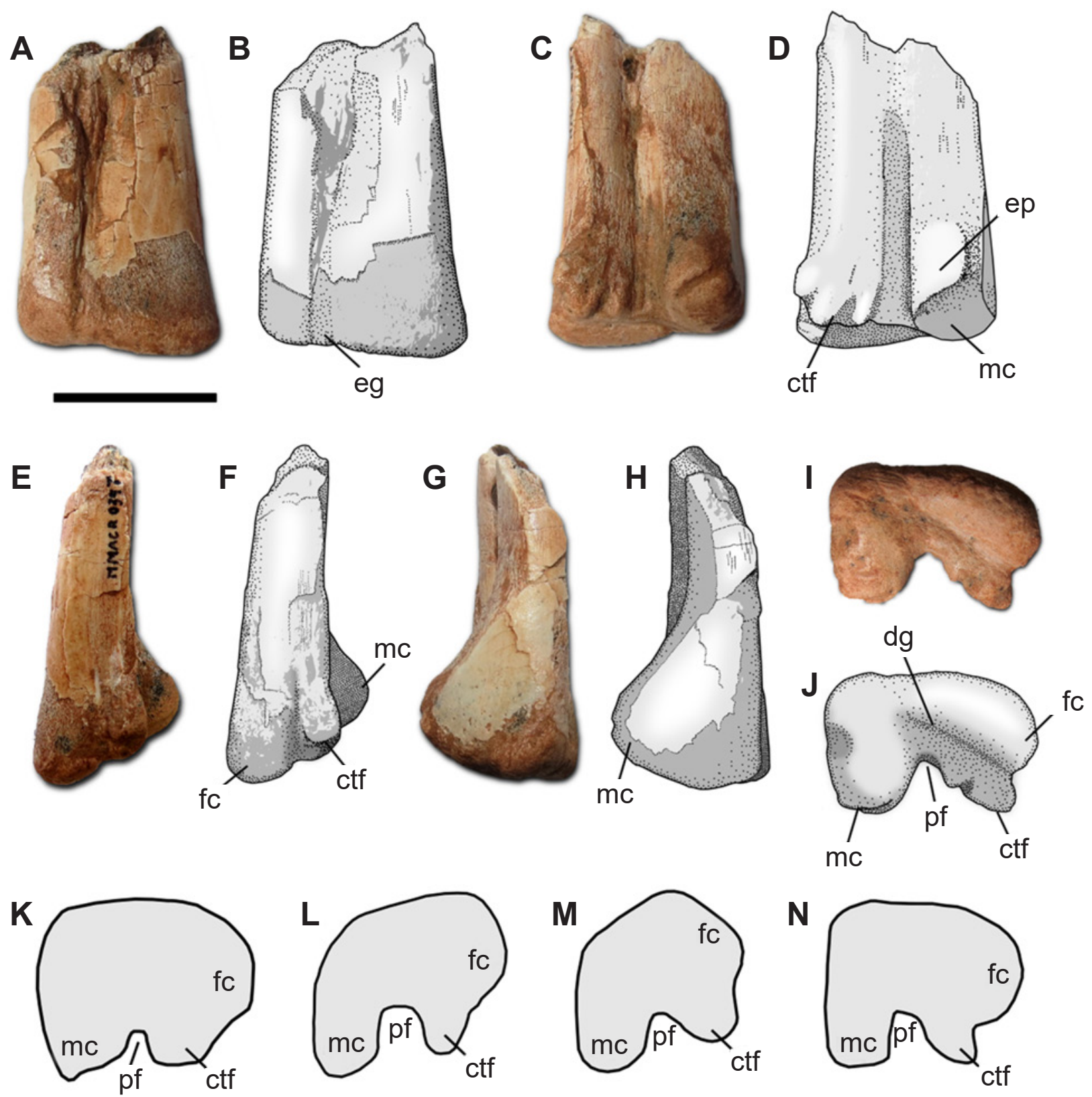

Figure 2. A-J, specimen MMACR 039 T, photographs and interpretative drawings in A-B, anterior; C-D, posterior; E-F, lateral; G-H, medial and I-J distal views. K-N, selected Triassic dinosaur femora in distal view. K, Herrerasaurus (redrawn from Novas, 1993, mirrored). L, Pampadromaeus (redrawn from Müller et al., 2015). M, Eocursor (redrawn from Butler, 2010, mirrored). N, Liliensternus. Abbreviations: ct, crista tibiofibularis; dg, distal groove; eg, extensor groove; ep, epicondyle; fc, fibular condyle; mc, medial condyle; pf, popliteal fossa. Scale bar: A-J = 20 mm; $\mathbf{K}-\mathbf{N}=$ not to scale. 
The crista tibiofibularis is deflected laterally, tapering posterolaterally into a pointed tip (Figures 2I,J), being separated from the rounded fibular condyle by a welldeveloped lateral groove, a distinctive feature of neotheropods. A laterally deflected crista tibiofibularis is widespread among neotheropods (e.g. Welles, 1984; Allain, 2001), but is also present in Sauropodomorpha (e.g. Saturnalia, Plateosaurus) and silesaurids (e.g. Sacisaurus), although generally to a lesser degree than represented in MMACR 039 T (Langer, 2003, fig. 4; Langer \& Ferigolo, 2013, fig. 17). The crista tibiofibularis of Eoraptor, albeit laterally deflected, has a rounded outline (Sereno et al., 2013).

In distal view, MMACR $039 \mathrm{~T}$ displays a deep, mostly straight, distal groove (Figures 2I,J), anterior to which the distal surface expands to form the distal corpus of the fibular condyle. A posterior expansion is absent (Figures 2E,F), contrasting with the condition of basal sauropodomorphs, such as Saturnalia and Pampadromaeus, where the distal surface is also elevated posteriorly, contributing to the crista tibiofibularis (Langer, 2003; Müller et al., 2015).

\section{DISCUSSION}

MMACR $039 \mathrm{~T}$ can be distinguished from known herrerasaurids (Figure 2K) by the presence of a deep popliteal fossa, an incipient extensor groove on its anterior surface and a laterally deflected, pointed, tibiofibular crest, separated from the fibular condyle by a sharp groove (Novas, 1993; Alcober \& Martínez, 2010; Bittencourt \& Kellner, 2009). An extensor groove and a tibiofibular crest separated from the fibular condyle by a deep sulcus are also absent in most silesaurids (e.g. Sacisaurus, but see below), sauropodomorphs (Figure 2L) and early ornithischians (Figure 2M), from which MMACR $039 \mathrm{~T}$ can also be distinguished by the anterior margin of the distal femur forming an angle close to $90^{\circ}$ with the medial one. Moreover, basal ornithischians, such as Eocursor, have a markedly convex anterior surface on their distal femur, formed mainly by an anterolateral projection of the fibular condyle (e.g. Butler, 2010, fig. 15). A similar condition is also present in silesaurids such as Sacisaurus (Langer \& Ferigolo, 2013).

Several features are consistent with the attribution of MMACR 039 T to Neotheropoda (Figure 2N). An acute angle formed between the medial margin of the medial condyle and the anterior surface of the distal femur, although also present in some herrerasaurids is common among neotheropods (see above). This is also true for a laterally deflected, pointed tibiofibular crest, albeit this feature also seems to be widespread among basal sauropodomorphs (e.g. Langer, 2003) and silesaurids (e.g. Langer \& Ferigolo, 2013). In addition, the presence of a small epicondyle on the posterior surface of the medial condyle was regarded by Ezcurra \& Novas (2007) as a potential synapomorphy of Neotheropoda, even though this feature is not thorough discussed by these authors and its distribution among basal theropods needs further clarification. Furthermore, Langer (2003) observed that the lack of an elevation posterior to the distal groove (as is the condition in MMACR $039 \mathrm{~T}$ ) is characteristic of basal theropods, such as Liliensternus. Of particular relevance is the presence of an extensor groove on the anterior surface of the femur, a character that, although better developed in more derived tetanurans, is also present in some abelisauroids (Ezcurra \& Novas, 2007; Carrano et al., 2012). The distribution of this character among basal neotheropods, however, needs further investigation.

A yet undescribed silesaurid from the Carnian of Poland shares with MMACR $039 \mathrm{~T}$ a laterally deflected, pointed tibiofibular crest, separated from the fibular condyle by a deep sulcus (G. Niedźwiedzki, personal communication). The femur of the new silesaurid, however, lacks an extensor groove and has a convex anterior margin that forms an obtuse angle with the medial condyle.

Despite its fragmentary condition, the morphology of MMACR $039 \mathrm{~T}$ supports a neotheropod affinity for the specimen, at least until further evidence proves otherwise. The presence of a tibiofibular crest that is sharply distinguished from the fibular condyle by a deep sulcus is regarded by Ezcurra \& Novas (2007) as a probable synapomorphy of the Coelophysoidea, perhaps indicating the attribution of MMACR $039 \mathrm{~T}$ to this clade. Eoraptor lunensis, however, also presents a moderately deep groove between the tibiofibular crest and the fibular condyle (Sereno et al., 2013). It is remarkable that the ratio between the lateromedial width and the anteroposterior length of MMACR $039 \mathrm{~T}$ closely matches that in Coelophysis (NMMNH 42351).

The oldest neotheropods are known from fragmentary bones from the upper Carnian Chinle Formation, Arizona, and Dockun Group, Texas, USA (Hunt et al., 1998; Nesbitt et al., 2007; Nesbitt \& Ezcurra, 2015, but see Ramezani et al., 2014). Throughout the Norian, the Neotheropoda became relatively widespread, with several described taxa preserved mainly in Laurasian Upper Triassic deposits (see Langer et al., 2010b; Brusatte et al., 2010; Niedźwiedzki et al., 2014 and references therein for a review). The Gondwanan Norian neotheropod record is still scarce. In the South American Triassic, this clade is represented only by the coelophysoid Zupaysaurus rougieri from the upper levels of Los Colorados Formation (Arcucci \& Coria, 2003; Ezcurra \& Novas, 2007) and fragmentary remains from the Quebrada del Barro Formation, northwestern Argentina (Martínez et al., 2015). Remarkably, the fossil assemblage of 'Botucaraí Hill' probably correlates to the basal level of Los Colorados Formation, what is suggested by the presence of the dicynodont genus Jachaleria in both Argentinean and Brazilian deposits (Soares et al., 2011). Therefore, the attribution of MMACR $039 \mathrm{~T}$ to Neotheropoda makes it the oldest representative of this clade in South America.

The presence of a neotheropod in Norian strata of Brazil extends the Late Triassic distribution of this group in Western Gondwana. Furthermore, the new specimen draws attention to the still hidden dinosaur diversity in the Upper Triassic of Brazil, a shortcoming that will be addressed by more intensive collection efforts. 


\section{ACKNOWLEDGEMENTS}

The author would like to thank the students of the Universidade Federal do Pampa (Palaeontology course, 2015.1) for recovering the specimen described herein. R. Müller for providing photographs of Guaibasaurus holotype. F. Pretto and M. Sales for specimen photographs and comments on an early version; G. Niedźwiedzki, A. Strapasson, M. França and S. Nesbitt for discussion. Reviews by A. Martinelli and J. Bittencourt greatly improved the manuscript.

\section{REFERENCES}

Alcober, O.A. \& Martínez, R.N. 2010. A new herrerasaurid (Dinosauria, Saurischia) from the Upper Triassic Ischigualasto Formation of northwestern Argentina. Zookeys, 63:55-81. doi:10.3897/zookeys. 63.550

Allain, R. 2001. Redescription of Streptospondylus altdorfensis, Cuvier's theropod dinosaur, from the Jurassic of Normandy. Geodiversitas, 23:349-367.

Arcucci, A.B. \& Coria, R.A. 2003. A new Triassic carnivorous dinosaur from Argentina. Ameghiniana, 40:217-228.

Arcucci, A.B.; Marsicano, C.A. \& Caselli, A.T. 2004. Tetrapod association and palaeoenvironment of the Los Colorados Formation (Argentina): a significant sample from Western Gondwana at the end of the Triassic. Geobios, 37:557-568. doi:10.1016/j.geobios.2003.04.008

Bittencourt, J.S.; Da-Rosa, A.A.S.; Schultz, C.L. \& Langer, M.C. 2013. Dinosaur remains from the 'Botucaraí Hill' (Caturrita Formation), Late Triassic of south Brazil, and their stratigraphic context. Historical Biology, 25:81-93. doi:10.1080/08912963. 2012.694881

Bittencourt, J.S. \& Kellner, A.W.A. 2009. The anatomy and phylogenetic position of the Triassic dinosaur Staurikosaurus pricei Colbert, 1970. Zootaxa, 2079:1-56.

Bonaparte, J.F.; Ferigolo, J. \& Ribeiro, A.M. 1999. A new early Late Triassic saurischian dinosaur from Rio Grande do Sul state, Brazil. National Science Museum Monographs, 15:89-109.

Butler, R.J. 2010. The anatomy of the basal ornithischian dinosaur Eocursor parvus from the lower Elliot Formation (Late Triassic) of South Africa. Zoological Journal of the Linnean Society, 160:648-684. doi:10.1111/j.1096-3642.2009.00631.x

Brusatte, S.L.; Nesbitt, S.J.; Irmis, R.B.; Butler, R.J.; Benton, M.J. \& Norell, M.A. 2010. The origin and early radiation of dinosaurs. Earth-Science Reviews, 101:68-100. doi:10.1016/j. earscirev.2010.04.001

Carrano, M.T.; Benson, R.B.J. \& Sampson, S.D. 2012. The phylogeny of Tetanurae (Dinosauria: Theropoda). Journal of Systematic Palaeontology, 10:211-300. doi:10.1080/1477201 9.2011 .630927

Ezcurra, M.D. \& Novas, F.E. 2007. Phylogenetic relationships of the Triassic theropod Zupaysaurus rougieri from NW Argentina. Historical Biology, 19:35-72. doi:10.1080/08912960600845791

Horn, B.L.D.; Melo, T.M.; Schultz, C.L.; Philipp, R.P.; Kloss, H.P. \& Goldberg, K. 2014. A new third-order sequence stratigraphic framework applied to the Triassic of the Paraná Basin, Rio Grande do Sul, Brazil, based on structural, stratigraphic and paleontological data. Journal of South American Earth Sciences, 55:123-132. doi:10.1016/j.jsames.2014.07.007
Hunt, A.P.; Lucas, S.G.; Heckert, A.B.; Sullivan, R.M. \& Lockley, M.G. 1998. Late Triassic dinosaurs from the western United States. Geobios, 31:511-531. doi:10.1016/S00166995(98)80123-X

Langer, M.C. 2003. The pelvic and hind limb anatomy of the stemsauropodomorph Saturnalia tupiniquim (Later Triassic, Brazil). Paleobios, 23:1-40.

Langer, M.C.; Bittencourt, J.S. \& Schultz, C.L. 2010a. A reassessment of the basal dinosaur Guaibasaurus candelariensis, from the Late Triassic Caturrita Formation of south Brazil. Earth and Environmental Science Transactions of the Royal Society of Edinburgh, 101:301-332. doi:10.1017/S175569101102007X

Langer, M.C.; Ezcurra, M.D.; Bittencourt, J.S. \& Novas, F.E. 2010 b. The origin and early evolution of dinosaurs. Biological Reviews, 85:55-110. doi:10.1111/j.1469-185X.2009.00094.x

Langer, M.C. \& Ferigolo J. 2013. The Late Triassic dinosauromorph Sacisaurus agudoensis (Caturrita Formation: Rio Grande do Sul, Brazil): anatomy and affinities. In: S.J. Nesbitt; J.B. Desojo \& R.B. Irmis (eds.) Anatomy, phylogeny and palaeobiology of early Archosaurs and their kin, London, Geological Society of London, p. 353-392 (Special Publication 379). doi:10.1144/SP379.16

Marsicano, C.A; Irmis, R.B.; Mancuso, A.C.; Mundil, R. \& Chemale, F. 2016. The precise temporal calibration of dinosaur origins. Proceedings of the National Academy of Sciences, 113:509-513. doi:10.1073/pnas.1512541112

Martínez, R.N.; Apaldetti, C.; Correa, G.; Colombi, C.E.; Fernández, E.; Malnis, P.S.; Praderio, A.; Abelín, D.; Benegas, L.G.; AguilarCameo, A. \& Alcober, O. 2015. A new Late Triassic vertebrate assemblage from northwestern Argentina. Ameghiniana, 52:379390. doi:10.5710/AMGH.27.04.2015.2889

Müller, R.T.; Langer, M.C.; Cabreira, S.F. \& Dias-Da-Silva, S. 2015. The femoral anatomy of Pampadromaeus barberenai based on a new specimen from the Upper Triassic of Brazil. Historical Biology, 28:656-665. doi:10.1080/08912963.2015.1004329

Nesbitt, S.J. \& Ezcurra, M. 2015. The early fossil record of dinosaurs in North America: A new neotheropod from the base of the Upper Triassic Dockum Group of Texas. Acta Palaeontologica Polonica, 60:513-526. doi:10.4202/app.00143.2014

Nesbitt, S.J.; Irmis, R.B. \& Parker, W.G. 2007. A critical reevaluation of the Late Triassic dinosaur taxa of North America. Journal of Systematic Palaeontology, 5:209-243. doi:10.1017/ S1477201907002040

Niedźwiedzki, G.; Brusatte, S.L.; Sulej, T. \& Butler, R.J. 2014. Basal dinosauriform and theropod dinosaurs from the mid-late Norian (Late Triassic) of Poland: Implications for Triassic dinosaur evolution and distribution. Palaeontology, 57:11211142. doi:10.1111/pala. 12107

Novas, F.E. 1993. New information on the systematics and postcranial skeleton of Herrerasaurus ischigualastensis (Theropoda: Herrerasauridae) from the Ischigualasto Formation (Upper Triassic) of Argentina. Journal of Vertebrate Paleontology, 13:400-423.

Pretto, F.A.; Schultz, C.L. \& Langer, M.C. 2015. New dinosaur remains from the Late Triassic of southern Brazil (Candelária Sequence, Hyperodapedon Assemblage Zone). Alcheringa, 39:264-273. doi:10.1080/03115518.2015.994114

Ramezani, J.; Fastovsky, D.E. \& Bowring, S.A. 2014. Revised chronostratigraphy of the Lower Chinle Formation strata in Arizona and New Mexico (USA): High-precision U-Pb geochronological constraints on the Late Triassic evolution of dinosaurs. American Journal of Science, 314:981-1008. doi:10.2475/06.2014.01 
Sereno, P.C.; Martínez, R.N. \& Alcober, O.A. 2013. Osteology of Eoraptor lunensis (Dinosauria, Sauropodomorpha). Journal of Vertebrate Paleontology, 32:83-179. doi:10.1080/02724634.2 013.820113

Soares, M.B.; Schultz, C.L. \& Horn, B.L.D. 2011. New information on Riograndia guaibensis Bonaparte, Ferigolo \& Ribeiro, 2001 (Eucynodontia, Tritheledontidae) from the Late Triassic of southern Brazil: anatomical and biostratigraphic implications. Anais da Academia Brasileira de Ciências, 83:329-354. doi:10.1590/S0001-37652011000100021
Welles, S.P. 1984. Dilophosaurus wetherilli (Dinosauria, Theropoda) osteology and comparisons. Palaeontographica A, 185:85-180.

Zerfass, H.; Lavina, E.L.; Schultz, C.L.; Garcia, A.J.V.; Faccini, U.F. \& Chemale Jr., F. 2003. Sequence stratigraphy of continental Triassic strata of Southernmost Brazil: a contribution to Southwestern Gondwana palaeogeography and palaeoclimate. Sedimentary Geology, 161:85-105. doi:10.1016/S00370738(02)00397-4

Received in April, 2016; accepted in July, 2016. 